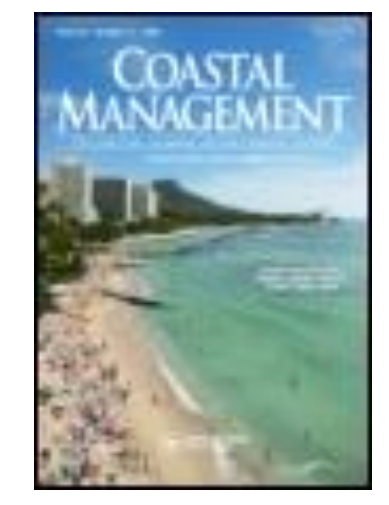

Coastal Management

VOLUME 38, ISSUE 3, 2010

SPECIAL ISSUE: SuSTAINABLE COASTAL COMMUNITIES AND ECOSYSTEMS

http://www.tandfonline.com/doi/full/10.1080/08920753.2010.483174\#.Uo_Ouie6SSo

\title{
Small Scale Fisheries Management: Lessons from Cockle Harvesters in Nicaragua and Tanzania
}

DOI:

$10.1080 / 08920753.2010 .483174$

$\underline{\text { Brian Crawford }}^{\mathrm{a}}, \underline{\text { Maria D. Herrera }}^{\mathrm{a}}, \underline{\text { Nelvia Hernandez }}^{\mathrm{b}}, \underline{\text { Carlos Rivas Leclair }}^{\mathrm{b}}, \underline{\text { Narriman }}$ ${\underline{\text { Jiddawi }^{c}}}^{\text {Semba Masumbuko }}{ }^{\mathrm{c}} \& \underline{\text { Maria Haws }}^{\mathrm{d}}$

pages $195-215$

Publishing models and article dates explained Published online: 01 Jun 2010

Article Views: 94 


\title{
Small Scale Fisheries Management: Lessons from Cockle Harvesters in Nicaragua and Tanzania
}

\author{
BRIAN CRAWFORD, MARIA D. HERRERA \\ Coastal Resources Center \\ University of Rhode Island \\ Narragansett RI 02882, USA
}

\section{NELVIA HERNANDEZ, CARLOS RIVAS LECLAIR}

Centro de Investigación de Ecosistemas Acuaticos

Universidad Centroamericana

\author{
NARRIMAN JIDDAWI, SEMBA MASUMBUKO \\ Institute of Marine Sciences \\ University of Dar es Salaam
}

\author{
MARIA HAWS \\ University of Hawaii at Hilo
}

\begin{abstract}
The role of women in gleaning fisheries tends to be underestimated and poorly documented although they play an important role in coastal food security and income generation. This paper describes two initiatives for co-management of women dominated cockle (Anadara spp.) fisheries implemented in Zanzibar Tanzania and Nicaragua that were based on a Fiji example. In each case, significant progress was made at the pilot scale but required adaptation to the community and national context. The Nicaragua case resulted in increasing densities of cockles inside and outside small scale no-take zones in a small estuary after a two year period of implementation. In Zanzibar, out of several no-take sites established on reef flats, only one showed similar results. Varying degrees of poaching affected both locations and continues to be an issue. In Zanzibar, local and national government played highly supporting roles whereas in Nicaragua, local government was supportive but national government continues to exhibit top-down decision making, while still evaluating the alternative co-management approach. In both cases, university extension initiatives were influential in building community capacity for management and playing an advocacy role with national government. Both locations are poised for scaling up to more geographic sites as well as fostering policy change that can lead to more integrated and ecosystem-scale approaches to sustainable fisheries management.
\end{abstract}

Keywords community-based, fisheries management, gender, gleaning, Zanzibar, Nicaragua 


\section{Introduction}

There has been much debate recently concerning the status of fish stocks world wide with many authors considering capture fisheries to be in a state of crisis due to too many fishermen chasing too few fish (Pauly et al. 1998, Jackson et al. 2001, Meyers and Worm 2003). On the other hand, many authors have pointed out that there are numerous examples of successful fisheries management that if replicated more widely, can stem the impending worldwide decline (Beddington et al. 2007, Hillborn 2007). Calls for reform in fisheries management include addressing overcapacity in harvest capabilities, increased use of co-management regimes, decentralization of authority, application of rights based mechanisms, increasing use of no-take marine reserves, as well as application of ecosystem-based management approaches.

Moving towards more sustainable fisheries practices is considered especially difficult in developing countries where most of the fish is harvested by small scale fishers that can number in the millions, where landings sites are numerous and highly dispersed, and coupled with weak capacity of governance institutions. While many of these management approaches may be successful in the northern countries where there are strong enabling conditions, governance and research capacity, and a much smaller number of fishing vessels, fishermen and landing sites, their application in developing country contexts may be more difficult or not applicable without significant modification and adaptation.

There is also increasing recognition that not only men, but women and children make significant contributions to the fisheries sector (Williams et al. 2004). Small-scale fisheries management requires better incorporation of gender dimensions and equity considerations, especially in management decision making (Diamond 2006). The role of women in capture fisheries is generally viewed as mainly in the post harvest sector. However, their contribution is especially important in gleaning - the harvesting of marine resources with simple implements or by hand in the intertidal zone, with the bulk of the catch consisting of bivalves and other invertebrates - but typically unreported or under-reported in fisheries statistics. Gleaned species are typically characterized by high yields due to high levels of natural productivity of tropical intertidal zones in estuaries and reef flats. A large component of these harvests is for subsistence use and therefore important in household food security, but they provide significant monetary contributions as well.

Emerging models of successful management of this type of fishery are found in the Western Pacific (Tawake et al. 2001). In this case, predominantly women gleaners established no-take zones on the reef flats to manage important gleaned species, especially Anadara spp. that were recognized by village chieftans and established with technical support from the Department of Fisheries and The University of the South Pacific. This use of no-take marine reserves is an increasingly popular approach to small scale fisheries management. There is a growing body of evidence that they can be effective in many parts of the globe (Russ and Alcala 1996, McClanahan and Mangi 2001, Roberts 2001, Halpern and Warner 2002), and that small sized reserves can be as effective as large scale reserves (Halpern 2003). In addition to Tawake et al. (2001), enhanced settlement and recruitment of bivalves in areas adjacent to no-take reserves has been reported (Rice et al. 1989, Murawski et al. 2000). There is also evidence if not sited or managed properly, crowding of mulloscs may stunt growth or reduce reproductive output (Bene and Tewfik 2003, Rice 2006, Marroquin-Mora and Rice 2008). Unlike finfish populations where adult spillover is an important reserve function, bivalves are a bit unique as they cannot move out of no-take areas. In the case of sedentary bivalves, marine reserves function to preserve and build up spawning stock biomass. However, periodic thinning of 
populations inside the no-take zones may be needed (Rice 2006). In fact, short term periodic openings of closed areas that are traditionally managed in some instances have shown better conservation performance than co-managed or centrally managed systems (McClanahan et al. 2006).

\section{Project Objectives}

Our premise in the Sustainable Coastal Communities and Ecosystems (SUCCESS) project was that the general Fiji-style model for small scale fisheries management (especially Anadara spp.) using a co-management approach that is coupled with no-take reserves has high transferability worldwide. In addition, we set out to examine whether low cost small scale pilot initiatives can be used to demonstrate and argue for changes in the enabling environment that can catalyze scaling-up for widespread impact. Lastly, we wanted to highlight the role of women harvesters and the increasing need to build their capacity to sustain productive intertidal fisheries that have significant food and economic security implications in coastal communities around the world. This paper consists of two cases from Tanzania and Nicaragua where conventional management was not considered to be performing effectively. In Nicaragua, there was poor compliance with seasonal bans, and in Tanzania, there was no specific management regime for cockles whatsoever. The project piloted demonstration comanagement initiatives that we believed if successful could be used to leverage improved enabling conditions supporting a co-management approach wore broadly within each nation. These cases are described below.

\section{Cockle Harvesting in the Aserradores Estuary of Nicaragua}

\section{BACKGROUND}

As the second poorest nation in the Americas, communities along this section of Nicaragua's Pacific coast are greatly impoverished with poor access to services, markets or other opportunities. Within this backdrop of poverty, increasing exploitation of fish and bivalve stocks, and removal of mangroves have combined with rapid local population growth to make income generation and food security increasingly tenuous for the people living within this area. These communities also coexist with several protected areas created to conserve the rich biodiversity of this region. However, these protected areas and other central government regulations have placed increasing levels of restriction on extractive activities such as cockle gathering which is an important source of food and income. While these actions have been a response to a growing concern about the sustainability of current resource use practices, there is also concern as to the effectiveness of the exiting management responses, both within the protected areas and in non-protected areas. The SUCCESS Program in Nicaragua decided to address these problems and concerns by focusing on several activities targeted at the natural resource dependent communities within and outside these protected areas. This included supporting the development of supplemental livelihoods and experimenting with alternatives approaches to sustainable fisheries management. These activities were implemented by Centro de Investigación de Ecosistemas Acuaticos (CIDEA) at the Universidad Centroamericana (UCA). 

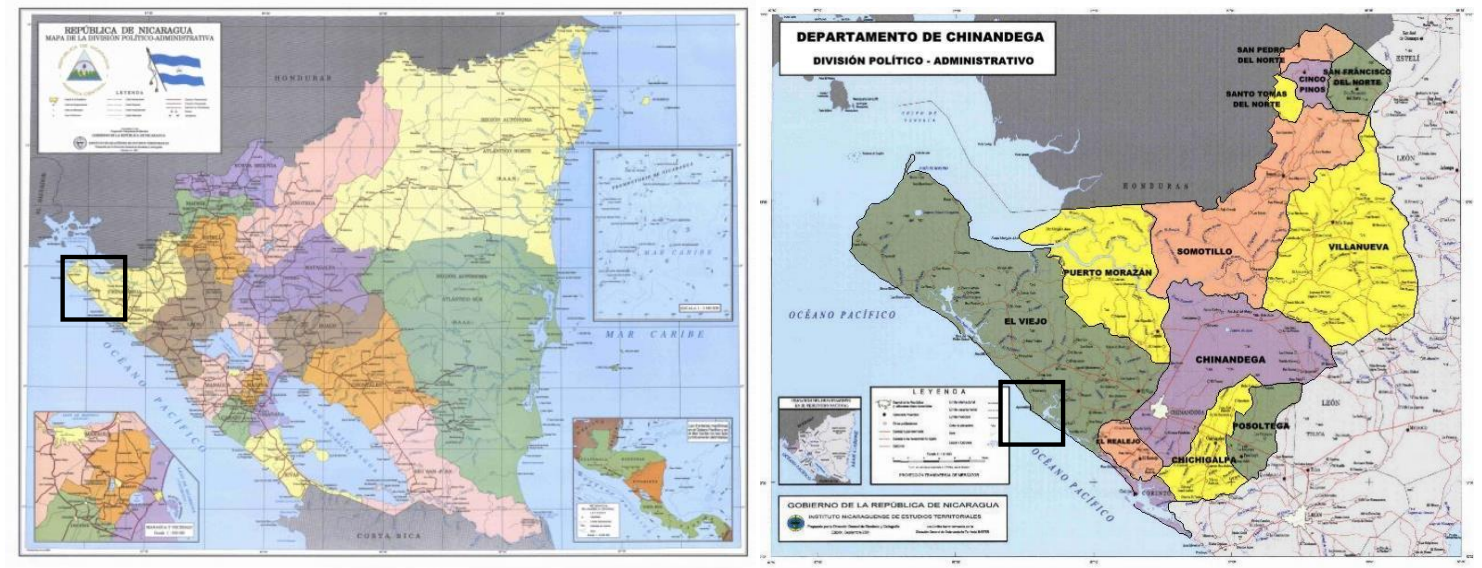

Figure 1: Location of the Aserradores Estuary.

One of the focal areas for the SUCCESS activities was the Aserradores estuary (see Figure 1) located Nicaragua within the municipality of El Viejo. The communities bordering this estuary are small fishing villages whose main populations were relocated to the area after the 1992 tsunami. The main earnings of local households rely heavily on coastal fisheries and cockle harvesting. Other livelihood opportunities in this area are very limited. Most of the families live in simple housing made with mangrove wood, plastic or tin roofs. For most households, there is a lack of sanitary systems, electricity or potable water. Social conditions are also poor. The number of school teachers in the region is low, and many children do not attend school as they work to support their parents, sometimes providing the only source of income for the family. A substantial percentage of households are headed up by single women. Alcoholism and family abandonment by men is also high.

\section{SOCIOECONOMIC IMPORTANCE OF THE COCKLE FISHERY}

Mollusk harvesting of Anadara and other species is an important activity in all of the estuaries dotting the Pacific Coast. In 2005, approximately two thousand people made their living from cockle harvests. Current estimates place the number of people harvesting cockles at five thousand. This significant increase has been attributed to increasing unemployment and the current economic crisis in which Nicaragua finds itself. Furthermore, decreasing catches in the coastal fisheries has forced more people into cockle harvesting. Increasing commercialization through peddler women is also contributing to increasing numbers of harvesters as its potential to generate quick cash increases.

A CIDEA census of fishers and cockle harvesters in the Aserradores estuary enumerated 111 cockle gathers and 34 fishermen. Women (43\%) and their children between eight and fifteen years old (32\%) are the main gathers of black cockles in the Aserradores Estuary. Ninety five percent of all adult women in the community harvest cockles. Adult males make up $88 \%$ of the fishermen with the remainder consisting of children under 18 years of age. Adult males make up $24 \%$ of the cockle gatherers in the estuary. The harvesting frequency of cockles depends on the success of the fishermen. In other words, if fish catches are good, women and children do not need to gather cockles. When catches are poor, this is the default food and income substitute which demonstrates the importance of the cockle fishery for household food and income security. 
A market study of the black cockle in Nicaragua, and Central America conducted by CIDEA (Gutierrez, 2005) documented increasing consumption of these products in the region and that much of this is unreported in national statistics. Hence, the importance of the fishery is not fully realized by fisheries managers and policy makers, and the increasing regional trade places increasing pressure on already highly stressed stocks.

\section{Current Management Practices}

Due to resource overexploitation, in 1992, the Ministry of Environment and Natural Resources (Ministerio del Ambiente y los Recursos Naturales, MARENA) declared a seasonal closure from April 15th to July 15th of each year for two main cockle species (Anadara similis $y$ Anadara tuberculosa). This regulation was again ratified in 2001 and is currently in force. In addition to the seasonal closure, gleaning and commercialization activities are totally banned in protected areas. This is the case of Padre Ramos estuary, one of the main locations of illegal gleaning activities.

While these management regulations may be sound from a biological perspective, permanent closures in entire estuaries and long seasonal closures create undo hardships for the people that depend on these harvests for their livelihoods. The reality is that many harvesters are forced to violate these prohibitions and harvest illegally either to provide an important source of food protein, or income needed for their families. Compliance with these rules is low. In addition, management authorities have limited resources and are unable to fully enforce these regulations. Prospects of increased resources for stronger enforcement actions are unlikely. In this situation, where substantial enforcement resources are not available, high levels of noncompliance result in ineffective management of the fishery. Cockle harvesters have reported a continual decline in catch rates over time in almost all locations along the Pacific Coast.

\section{An Alternative Management Approach}

Given that the current highly centralized management regime has failed to effectively manage wild harvests of the black cockle, the SUCCESS project proposed to experiment with a different approach that has been tested effectively in other parts of the world. This is the application of community-based small-scale permanent marine reserves interspersed with open fishing areas. Small-scale no-take marine reserves have been shown to be an effective biodiversity conservation tool as well as an effective means of enhancing fisheries production (Russ and Alcala 1998, Mclanahan and Mangi, 2001, Roberts et al. 2001, Halpern and Warner 2002, Halpern 2003). When conventional practices fail or create undue burdens on small scale fishers, this has become a management tool of choice in much of South East Asia and the Pacific Islands where hundreds of community managed reserves have been established in a number of nations. This approach has also been applied successfully in Fiji where large numbers of women harvest cockles (Tawake 2001), a similar situation to Nicaragua.

This approach is predicated on high levels of participation and decision making by local harvesters on setting management rules such as determining the location and size of the closed areas. It also requires their active engagement in management - monitoring of the resource, enforcement of the no-take ban in permanent closed areas and sanctioning local violators. High levels of community participation in planning and management decision making creates high perceptions of legitimacy of the rules and therefore high compliance through creation of social capital and through social networks (Crawford et al. 2004). In this approach, once reserves are established, the community shoulders much of the management costs (reducing burdens on central management agencies), but they also are the main beneficiaries of their 
efforts - improved catches of cockles. In Fiji, participatory monitoring of "Locally Managed Marine Areas" (LMMAs) - small scale community managed no-take zones - has shown an increase in abundance of cockles of 200-300 percent after 1-3 years of closures in adjacent open fishing areas. Abundance and size frequency inside the no-take zone increased to a greater extent than in the open areas. Higher harvests occurred in the downstream side of the no-take zone, demonstrating enhanced recruitment to the area open to fishing, the result expected from permanent adjacent area closures (Tawake 2001). This enhanced production outside the reserve areas, through enhanced recruitment of spat from large numbers of large adults inside the sanctuary is of direct benefit to harvesters.

CIDEA requested permission from MARENA to test this management approach with the communities surrounding the banks of Aserradores Estuary to determine whether this approach, which has been proven effective elsewhere in the world, can be effective in Nicaragua. This estuary is relatively isolated, contains a small number of cockle gathers with few influences of outside harvesters- ideal pre-conditions for a community-based approach and therefore a good site for a pilot initiative. MARENA agreed to this experiment under the condition that CIDEA staff followed procedures required by the permit issued by MARENA including keeping them informed of progress and results. This was extremely important for gaining support later on from MARENA in considering official adoption of new management policies based on this experience. The premise was that if the community could successfully manage the cockles in the estuary, and this was well documented with hard data, MARENA could use this evidence to support a change in their management approach from a more topdown nation-wide closure, to a more community-based co-management approach that could be applied elsewhere in the country for the cockle fishery.

\section{The Planning Process}

Once MARENA gave permission to engage in the "experiment" CIDEA started activities in 2006 by gathering together residents from Aseradores for a series of meetings over a six month period. Concurrent to these meetings, CIDEA conducted a baseline socioeconomic survey and a census of cockle harvesters in the whole estuary.

The meetings were attended mainly by women and children. In the planning meetings CIDEA extension staff asked residents to discuss trends in cockle harvests and associated problems. CIDEA explained to participants, basic biology of the cockle, the importance to adequately manage stocks, and the rationale behind the alternative management approach using permanent small-scale no-take zones. CIDEA staff made simple presentations supplemented with videos about the proposed approach. As extension staff became more involved in the community and with the cockle group, the harvesters gained trust and confidence to working with CIDEA. Initially, the group of women harvesters, who are mostly illiterate, could not see the benefits of this approach and could not see themselves taking control over management as means to improve their livelihoods. In initial meetings they were shy and not very talkative, so recreational activities were included where children could participate, and small presents given to children as a minor incentive to participate. The CIDEA extension officer designated to manage this activity was a women biologist with previous extension experience. In addition to organizing these meetings, she made follow-up visits to each of the cockle gather households. This social engagement and networking over time built trust among the extension agent and the community and built support for the idea. 
The extension staff showed harvesters how to set up no-take zones, and taught them how to monitor abundance of cockles in a simple but scientific way. Using pictures, stories, and examples from other places, the group gradually became familiar and interested in the concept. Consensus was reached after six months of formal meetings and countless informal discussions to set up one no-take area. However, the site they choose for the first no-take area did not have abundant populations of Anadara nor was it an important harvesting area. While the community was willing to experiment, they did not yet have confidence that it would succeed. At this site one family refused to stop harvesting. As the no-take zones were voluntary closures, the community could not sanction the poaching family other than through moral suasion. The community subsequently set up two additional no-take zones in part due to their increasing confidence in the community-based approach and the need to identify better no-take sites if they were to be truly effective. The group also decided to establish a five person management committee whose membership was decided by democratic vote. A total of 26 hectares of mangrove habitat were set aside as a permanent closure, located relatively close to the community settlement areas. The entire estuary including the water and mangrove areas is 11,687 hectares. The community used simple physical geographic features to mark boundaries - such as points, channels, and signposting among the mangrove roots with simple markers (painted coca-cola bottles found in the surrounding beaches by the children) to designate boundaries between open and closed areas. CIDEA also is now educating the Aserradores group concerning the importance of mangrove restoration as an additional strategy to maintain the estuarine ecosystem health and maintain important cockle habitat. Even at this small community scale, the community is incrementally learning and developing an ecosystem based approach to management of the estuary.

\section{COMMUNiTy-BASED MONITORING}

CIDEA established a community-based scheme to monitor the effectiveness of the no-take areas. CIDEA staff provided the community with training on data sampling and analysis. However, these concepts have proved difficult for the group to understand. Nevertheless, a resource baseline was established on the size frequency and average density of cockles in estuary. This first baseline sampling was carried out in September 2006 at nine locations (Fig. 2) including the three no take areas set up by the group. After six months, a second sampling was carried out inside the no take areas. Subsequent sampling occurred every six months. Starting in September 2007, in addition to sampling inside the no-take zones, the group also started monitoring adjacent areas approximately 100 meters from the boundaries of the no take zones. Sampling at each location (each no-take zone and a corresponding open adjacent area) consisted of randomly marking off several four square meter quadrats $(2 \mathrm{X} 2 \mathrm{~m}$.). The number and size of each cockle found in each quadrat was recorded. The number of replicate quadrats sampled per location varied from three to ten and was dependent on the number of community monitors available and tidal characteristics at each site. Sampling must be done during low low tides and the time available to finish sampling in any given day is dictated by the duration of the lowest tidal range that makes sampling possible. 


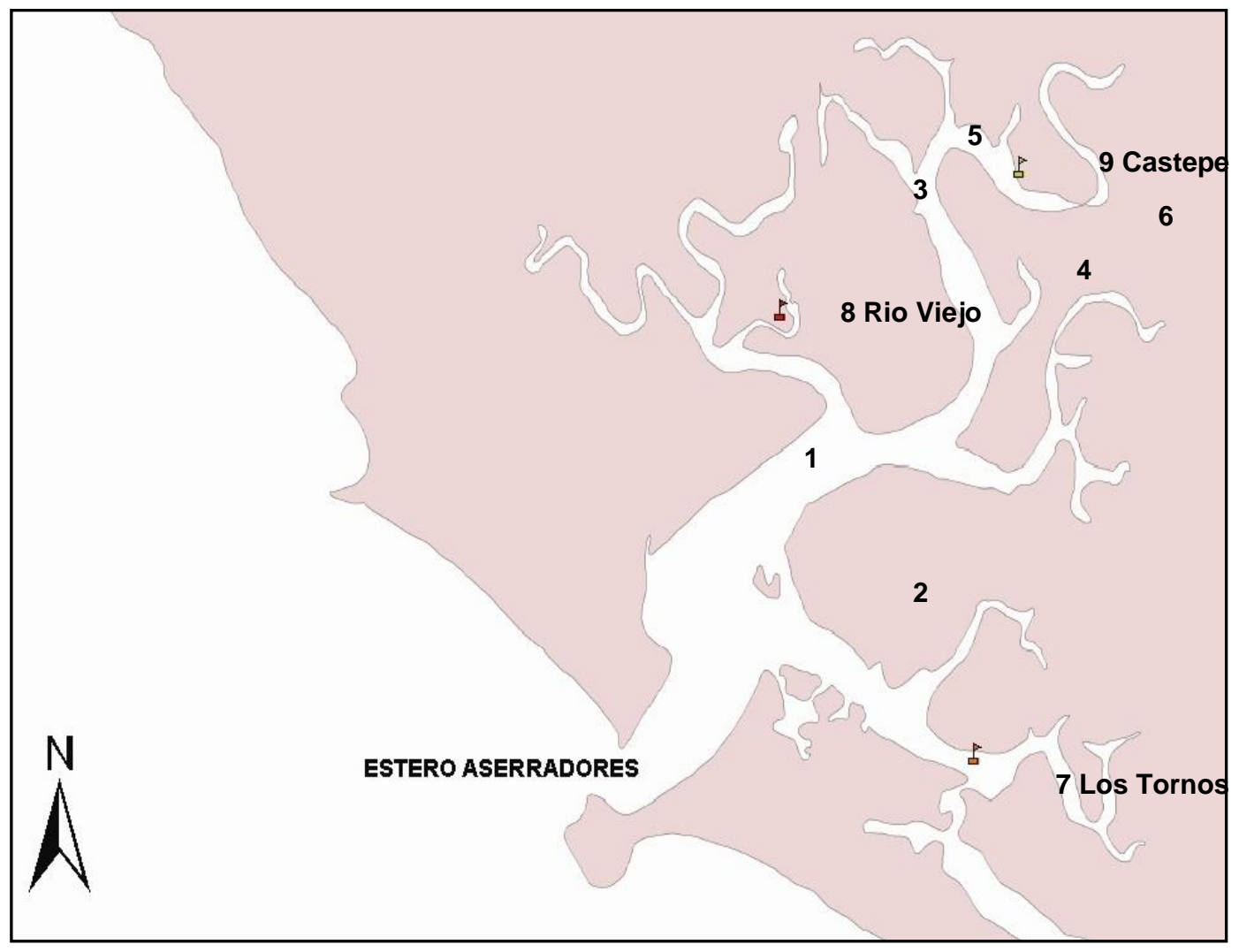

Figure 2. Monitoring Sites in Estero Aserradores.

The sampling strategy was set up to measure whether cockle abundance increased inside the closed no-take zones and adjacent outside areas. Figure 3 shows the mean density of cockles both inside the three no-take zones and in adjacent areas over time. While the density was almost the same for each group in Sept 2006, both groups increased over time, with a higher density inside the no-take zones in Sept 2007 and August 2008. Changes in cockle density over time were statistically analyzed. Mean density data was transformed $(\log 10)$ for statistical analysis as raw data was not normally distributed. Results reported below are for the Log 10 transformed data. Changes were statistically significant or all sampled areas combined, both inside and outside the no take zones (ANOVA: $\mathrm{N}=21$, Multiple R-square $=0.471$, Fratio $=8.012, \mathrm{p}<0.01)$. Changes in density over time only in areas outside the no-take zones were significant at the 0.1 alpha level (ANOVA: $\mathrm{N}=12$, Multiple R-square $=0.459$, F-ratio $=$ $3.813, \mathrm{p}=0.063)$. Changes in density over time inside the no-take areas were also significant at the 0.1 alpha level (ANOVA: $N=9$, Multiple R-square $=0.549$, F-ratio $=3.651, p=0.092$ ). The results suggest that a build up of cockle density inside the no-take zones resulted in increased abundance in adjacent areas. There were no measurable changes in overall cockle harvesting effort during this period. One family continued to harvest at the Rio Viejo no-take site (Site 8 in Figure 2) and would not agree to the voluntary closure. However, the rest of the community decided to maintain this site as a "no-take" zone as the monitoring data showed increases in cockle abundance in spite of the fact that one family continued harvesting at this site. New monitoring protocols are now being added to monitor the effects of these trends on catch rates of harvesters and income earnings from cockle harvests. 


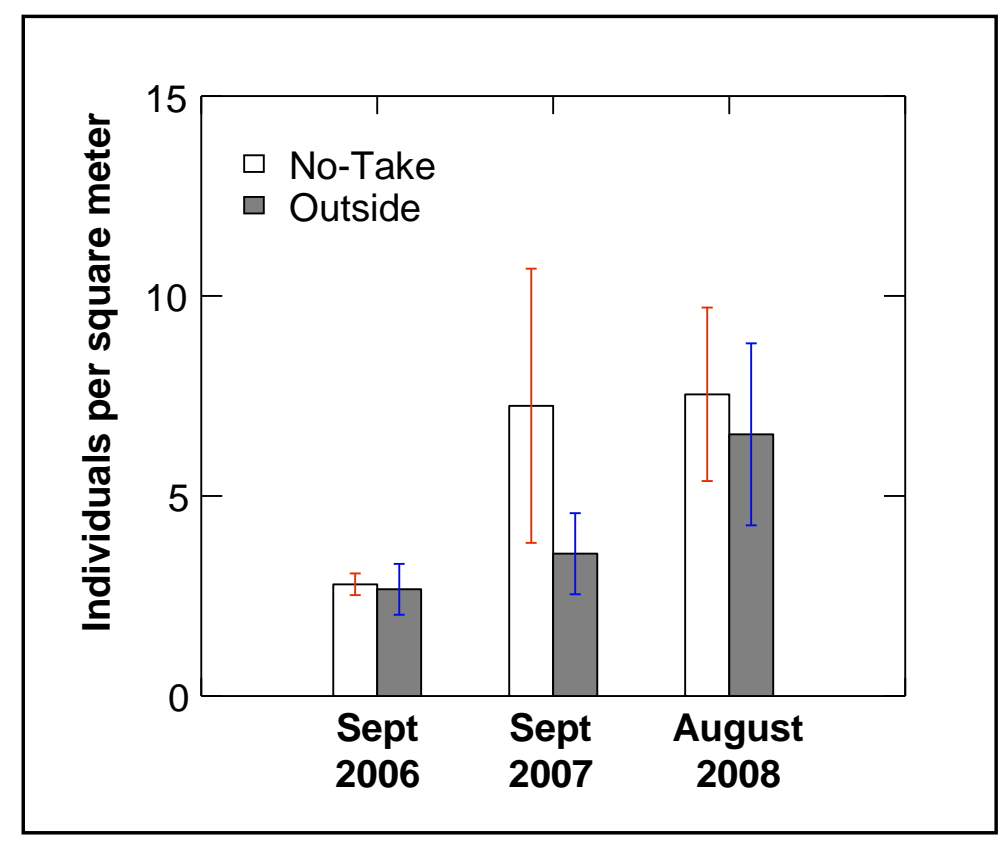

Figure 3. Changes in mean density of cockles inside and outside the no-take zones.

\section{INVOLVEMENT OF LOCAL AND NATIONAL GOVERNMENT}

Although the cockle harvesters became quite enthusiastic about this new approach to cockle management, they experienced several challenges along the way. MARENA and INPESCA (Instituto Nicaraguense de Pesca y Acuicultura,) unilaterally decided in 2007 that harvests from Aserradores could not be sold and did not allow permits to be issued for this purpose. The rationale for this decision was that the Aserraderos estuary is adjacent to the Padre Ramos protected area where no cockle harvesting is allowed. MARENA and INPESCA could not discern among cockles taken illegally from Padre Ramos and cockle taken legally from the Aserradores Estuary and therefore decided to ban all cockle harvest in this area. This decision was made in a classic top-down manner with no consultation of the local communities. This greatly discouraged the group and they considered placing roadblocks on the highway to protest. Extension staff from CIDEA suggested they enter negotiations with the national agencies instead of roadblocks. CIDEA staff helped to get the local government involved, which supported this alternative management approach and a lifting of the sales ban. CIDEA invited the local government and national agencies to visit the community and see and hear themselves what the community was doing. This resulted in an important agreement where MARENA and INPESCA agreed to allow the Mayors office to control the harvests from Aserradores estuary and issue commercial permits to the Aserradores cockle group. As part of this agreement, the cockle group was given responsibility to maintain the alternative management regime for the cockles. This agreement therefore provides a degree of formal delegation of responsibility from the central government to the Local municipality and the cockle harvesters to mange the harvest and sale of cockles from the estuary. Through the commercial permits, it also provides some degree of exclusive use rights (for the sale of cockles) to the community of harvesters.

\section{INTEGRATING SHELLFISH SANITATION}

Most coastal communities in Nicaragua have little if any accommodations for sanitation or have limited potable water. Gastrointestinal illnesses are common, and often fatal. The work in 
Nicaragua also entailed efforts to determine whether cockles presented a risk to the consumer by conducting water quality monitoring and analysis of cockle tissues. Water quality monitoring revealed a seasonal element to water quality-in the rainy season higher levels of $E$. coli were detected at nearly all sampling stations with concentrations high enough that consuming shellfish would be risky. Tissue analysis also revealed the presence of pathogens. In the dry season, levels of contamination diminished to the point at which most areas would be safe to gather shellfish from. These results provide two practical solutions. First, if closed seasons are necessary to protect the resource, then it would be more logical to have the closed seasons during the rainy season when consumption is the most risky (July-Dec) rather than in the dry season when consumption is safer (January to June). Currently the closed season is April to July when consumption peaks due to the Easter holiday when it is the tradition to consume shellfish.

This public health can help inform the fisheries co-management efforts. If permanent, closed no-take zones are the answer to maintaining the population, it may be most effective to position these in areas of high contamination so that the allowed gathering areas can be in the "safe" areas. Also, with sufficient public outreach, the contaminated nature of the shellfish in the closed areas may function as added incentive to local residents to respect the community guidelines not to collect shellfish in these areas. Additionally, initial marketing surveys in Nicaragua indicate that vendors and consumers would be willing to pay a higher price for shellfish which could be certified as coming from safe waters. This will soon be tested as cockles from the test depuration areas will be tested marketed with an university label attesting to their safety.

Shellfish sanitation is a key issue which ties together bivalve fisheries, food security and public health. In addition to the need to devote more attention to the bivalve fisheries management, shellfish sanitation also needs careful attention in order to protect the public health, enhance the food value of shellfish, add economic value, and open new opportunities for sustainable use of this neglected resource.

\section{LESSONS FROM ASERRADORES}

The Nicaragua and Central American coastline provides tremendous potential for sustainable gleaning activities that can both raise incomes of households in coastal communities as well as increase food security. This experience to date tends to indicate that local harvesters, predominantly women, can take control of and effectively manage resources on which their households heavily depend. This alternative management approach is showing great potential that can reduce socio-economic impacts on harvesters by current top-down centralized management practices while at the same time achieving conservation goals.

In this process of experimenting with a new management approach, there were different stages of learning for CIDEA and the community. This was a new and challenging extension initiative for CIDEA extension staff who previously had worked almost exclusively with shrimp farming clients. The extension team had to learn how to relate to people living in poor fishing communities and how to translate concepts and ideas for people with low levels of formal education. They had to learn how to tailor activities to fit the needs and constraints of predominately women audiences. They had to learn to understand their needs as individuals and as a community. They learned that real change is dependent on what the community decides to support for protecting or restoring their natural environment. They have seen the community evolve from a negative vision and not empowered to participate in any decisions 
regarding resource management to become an organized group working together and proposing new ways to make progress and look forward to a more sustainable future.

This approach was predicated on high levels of participation and decision making by local harvesters on setting management rules such as determining the location and size of the closed areas. However illiteracy and low self-esteem gave a character to these communities that influenced at first their predisposition to participate. CIDEA needed to persevere over many years to encourage them through creative events and activities, and blend both formal and informal approaches. It also requires their active engagement in management - monitoring of the resource, enforcement of the no-take ban in permanent closed areas and sanctioning local violators which sometimes it is complicated job.

Setting up the monitoring protocols as well as training the community to understand and implement them required a substantial investment of time and effort. Initially, they only wanted to collect cockles of a size they were used to harvesting, rather than all cockles especially smaller sized individuals. This selective sampling ran the danger of biasing results and needed to be constantly reinforced. Additionally sampling inside mangrove stands is much more difficult than on open mud banks or exposed reef flats and searching for all individuals inside the sample quadrats proved quite difficult. Although the monitoring group eventuially became quite proficient at collecting data, working with the community on the analysis of results also proved challenging.

The current results suggest that a management regime where local resources users are empowered to manage the fishery with a small amount of outside technical support can be effective. This pilot initiative however needs to be extended for a longer duration to ensure the preliminary results continue to reap economic benefits for the community. Tangible community benefits is a key factor in sustainability of community based costal management initiatives (Pollnac and Pomeroy, 2005). The Nicaraguan example also demonstrates the importance of an outside institution such as CIDEA providing support to the community, both in terms of facilitating the social process of organization and mobilization, participatory monitoring, and advocacy with the national fisheries agency.

After nearly three years of experience, the communities surrounding the Aserradores estuary that are dependent on cockle gleaning now have a firm commitment to preserve and restore their resource. The local government and national agencies (MARENA and INPESCA) have agreed to transform the experiment into a formalized community-based management agreement issuing commercialization permits with a commitment from the community to continue working in the estuary with this alternative approach. However, important challenges lie ahead at the national level. Aserradores is an exception to the rule and no new national policy has been proposed or established to allow this approach to be adopted throughout the Pacific coast of Nicaragua. Changing national policy can be a slow process and as an increasing number of communities start experimenting with this approach and a larger constituency for change builds this will put more pressure on the national agencies to formally consider adoption of such an approach.

While other donors and non-governmental institutions are interested in replicating this approach more widely, including for coastal fin fisheries management, more continuing support is needed for the Aserradores communities while attempting to scale-up to other areas. The Aserradores cockle harvesters are more empowered, but the role of CIDEA as an outside support service group is still critical in what is a formative and fragile arrangement as 
demonstrated in CIDEA's role in monitoring as well as facilitating negotiations with powerful central government agencies.

Another important challenge is emerging for the Aserradores communities. While compliance with the no-take areas is high among the local communities surrounding Aserradores, residents in other impoverished communities from the adjacent Estero el Realejo are starting to enter the Aserradores estuary to harvest mangrove wood and fisheries resources including cockles. These instances are becoming more and more frequent as resources in the adjacent estuaries continue to decline. This is a very difficult situation for the community to address by themselves. CIDEA is working with the community and with national and local authorities about possible strategies to prevent these outside poaching events. This highlights and reinforces the need for policy change at the larger scale. Nicaragua should consider issuing collective use rights to communities and/or user groups to manage the cockle fishery in each estuary as means of providing full legitimacy for each estuarine management group to exclude outsiders.

Nicaragua needs to consider additional management measures other than no-take zones. This includes maintaining a minimum size limit that allows most cockles to reach maturity and reproduce at least once before they are harvested and applying similar community use rights to management of mangroves as well. Therefore, the experience here represents only a beginning along a road of evolving fisheries policies towards an ecosystems approaches to more sustainable cockle fisheries within Nicaragua.

\section{Cockle Harvesting in Menai Bay on Zanzibar Island Tanzania}

\section{BACKGROUND}

The Menai Bay Conservation Area is located southwest of Unguja Island of Zanzibar. The bay, which covers an area of $470 \mathrm{~km}^{2}$ shelters 900 hectares of mangroves and approximately 2500 hectares of reef flats (Figure 4). The Resources Management and Conservation Act No. 10 of 1996 provides in the part for the establishment of community management areas with the purpose "to provide local communities or groups with a means of acquiring clear and secure rights to plan, manage and benefit from local forest resources, on a sustainable basis, in order to help meet local needs, stimulate income generation and economic development and enhance environmental stability"

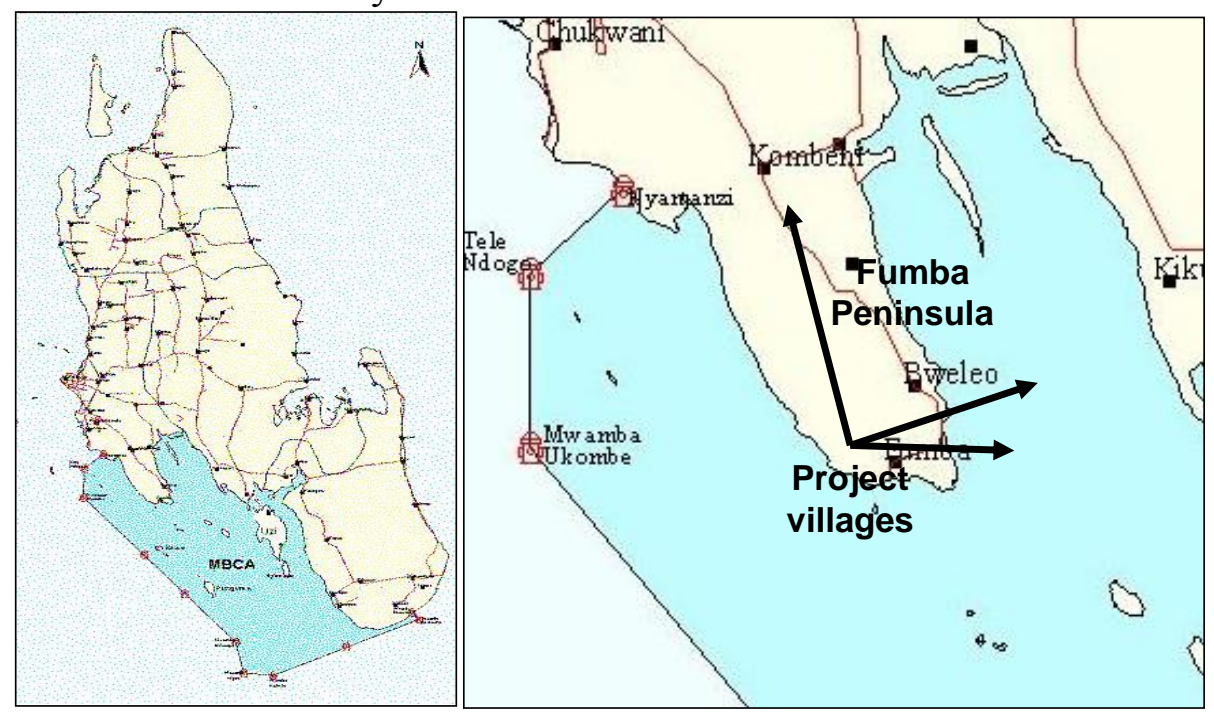


Figure 4: Location of the Menai Bay Conservation Area on Unjuga Island, Zanzibar.

The resources of this area remained relatively undisturbed until uncontrolled fishing pressure combined with destructive fishing methods became prominent, creating a range of environmental and sustainable use issues. Shallow waters, accessible to all kinds of boats, and the many islets provided an easy opportunity to establish fishing camps that made Menai Bay an attractive area for fishers and degraded easily. Since 1994 the Government of Zanzibar through the Ministry of Agriculture, Natural Resources, Environment and Cooperatives (MANREC) - now Ministry of Agriculture, Livestock and Environment (MALE) —with financial assistance from the World Wildlife Fund (WWF), provided support to coastal communities in the MBCA with the objective to enhance the management of these important coastal resources. The MBCA was established with the purpose to conserve in perpetuity the biological processes and productivity of the MBCA and associated ecosystem for the benefit of the local population (Ecoconsultants, 2005)

The Fumba Peninsula is located on the south west side of Unguja Island. It has four villages with a total population of 3,000 people (Makame et al. 2004). Three of these villages were selected for project interventions (Nyamanzi - 625 persons, Bweleo -842 persons, Fumba 909 persons). Most people make their livelihoods as fishers, seaweed farmers or gleaning mollusks from the intertidal reef flats adjacent to the shoreline.

\section{SOCIOECONOMIC IMPORTANCE OF THE COCKLE FISHERY}

Mollusk harvesting is an important economic activity among the coastal communities especially for the woman on the Fumba peninsula. Anadara spp. are the most common bivalves collected. However other species are also collected including gastropods such as Chicoreus sp., Plereuploca sp., and other bivalves such as Pinctada and Pteria. The number of people involved in gleaning is approximately 1000 persons as most households conduct this activity. The number of people harvesting has been steadily increasing, partly as a result of commercialization of Anadara spp. to easily accessible local and tourism markets in Zanzibar town.

Cockles (Anadara sp) are an important food source of economic importance to coastal communities. They are abundant in intertidal areas with rich sea grass and sand. Increased pressure on mollusk collection in near shore areas has caused drastic reduction of stocks, and therefore women now have to walk further in order to collect enough bivalves or go on boats to distant islands in the bay where the resource is much richer. The ease of collection and increasing exploitation has reached a crisis level.

The bivalve Anadara antiquata has been a subject of biological research in Tanzania (Shunula 2005, Matthes 1968, Kayombo 1986). However, the active involvement of women and children in the collection of this species its contribution to the protein requirements of especially poor households who are often not able to obtain fish has also been noted (Mwaiseje 1982).

Adult women and their children are the main gathers of the cockles in Fumba peninsula. Most of the harvesters are older women where three-quarters are between the ages of 30-50 years. Gleaning is normally conducted during the spring tides. They boil and process the cockles on the area just outside the beach. Most of the women are also seaweed farmers (92\%) and also 
collect other shellfish for their own consumption and for sale. Some also collect sea cucumbers. These two activities are normally conducted during spring tides. During the neap tides the women have other activities which contribute income to their house holds. These activities range from micro business which includes making bread (chapatti or mandazi), selling juice or coconuts, making fish cakes and cookies (vileja) as well as making charcoal. Most of the men in these villages work as fishers but a few are also involved in cockle harvesting. Men collect cockles primarily through diving which means they exploit populations unreachable by women at deeper depths.

Wild harvest is limited by the tides and in most locations collecting is possible approximately 10 days each month. Active shellfish collectors can harvest two 20 liter buckets of shellfish per day which can usually earn them approximately 20,000 to 30,000 Tanzanian Shillings per month (\$20-\$30), collecting 150-300 shellfish per day. This harvest consists of as many as 10 different species of gastropods and bivalves. These women earn an average of $\$ 35$ a month from all of their livelihood activities including reef gleaning and seaweed farming. Women who teach, have government jobs or have other daily micro business activities earn higher incomes of approximately $\$ 90$ per month. Women who only do part time bivalve collection earn approximately $\$ 10$ per month (Kite-Powell et al. 2004)

\section{Current Management Practices}

In spite of the fact that Menai Bay has been declared a conservation area and some restrictions have been placed on fishing inside the bay, collection of mulloscs and bivalves is open access with no restriction of size, numbers, gear or areas collected. Cockle harvesters collect both big and small bivalves. In 2003 they were mobilized under a McKnight funded project with IMS staff where smaller sized individuals were held and grown out in small $15 \mathrm{~m}^{2}$ fenced impoundments made of wooden stakes placed on the reef flat. (Powell et al. 2004). In spite of this initial attempt at some form of management, populations continued to decline.

\section{IMPLEMENTING AN Alternative MANAGEMENT APPROACH}

IMS, with funding through the SUCCESS project, conducted a series of participatory rapid appraisals with cockle harvesters on the Fumba Peninsula. Harvesters reported that sizes were declining and the amount of time needed to collect a can full of cockles took much longer than five or 10 years ago. They reported they had to go further distances to find abundant supplies as reef flat areas near the villages were heavily depleted. Since this local knowledge pointed to overfishing problems, idea of establishment of no take zone was introduced to the community (The Fiji locally managed marine area example was presented) as well as possible size limits. After a series of meetings and discussions the communities decided to establish four no take areas off of the villages of Bweleo, Nyamanzi, Fumba Bondeni and Fumba Chaleni (Fig. 5). Bylaws to mange the no-take zones were drafted by the communities themselves and signed by all three village heads. The approved village by-laws were then officially signed in 2007 by the district Fisheries Commissioner. The by-laws establish a management committee in each village with seven members including a chairperson, secretary, and treasurer. They include concerning punishment of poachers and require demarcation of the sites. A management plan was also drafted with the assistance of IMS. Outreach events to community members were made after the ordinances were approved to make sure all residents were aware of the boundaries of the no-take areas, the importance of cockle conservation, and the consequences for breaching the by-laws. Throughout this process, representatives of the MBCA have been actively supporting the no-take initiative. 


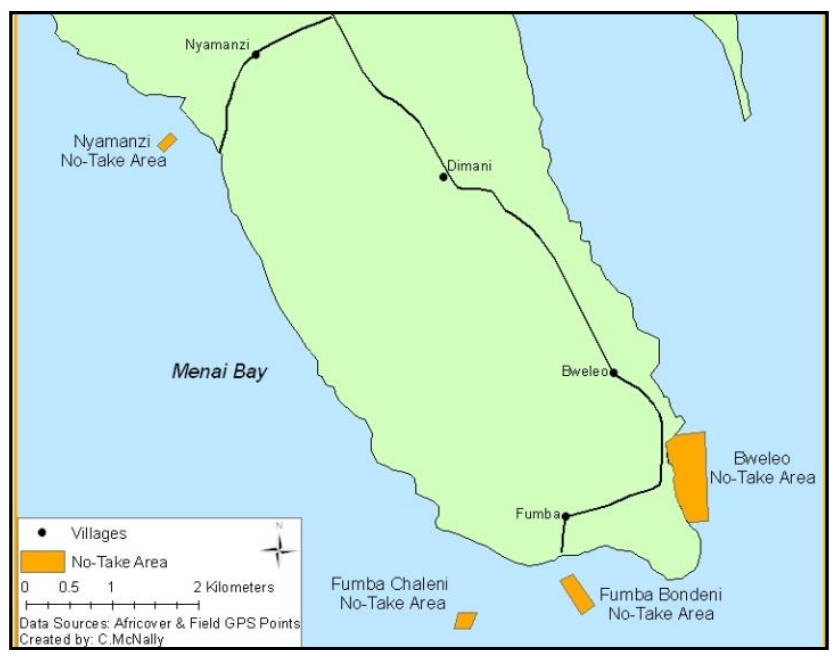

Figure 5. Location of community based no-take areas.

The Fumba Chaleni no-take zone ( 3 ha) is adjacent to fringing reef and unlike the other no-take zones is exposed only in high spring tides of North East monsoon winds. The site is covered by dense seagrass mainly Thalassia and Thalasodendron with sand and sand-muddy as substrate. In Nyamanzi village the no-take area ( 2 ha.) is exposed during low tides and habitats ranging from seagrass to patches of sand, mud, and rocky substrate. The site experiences very high seasonal change in habitat due to continually shifting sand resulting from monsoon winds (Ngowo, 2007). The Fumba Bondeni no take zone (6 ha) and the Bweleo no take zone (5 ha.) are located close to settlement areas and consist of relatively stable sandy bottom substrate with seagrass habitat.

Final decisions regarding site selection was made by the communities. However, the IMS team felt that some of the sites are not ideal from an ecological standpoint. For example, in Nyamanzi the no take zone was selected in an area where there is a seasonal movement of sand. In one season its rock and the other season its sand, so it is poor habitat for cockles and also experiences high periodic mortalities, making a build up of larger sized old spawning stock difficult. At Fumba Chaleni the no take zone is in an area that is frequently exposed during low tide and high daytime water temperatures at low tide cause high mortality. On the other hand, the no take zone of Bweleo is in an area of deeper water that is rarely dry during low spring tide and has been observed to have among the largest shells in the area. The area has traditionally been used by men for diving for cockles and personnel at a nearby military facility used the area to collect cockles and other resources as well raising some initial concerns about enforcing the no-take rule.

Although the cockle harvesters became quite enthusiastic about this new approach to cockle management, they experienced several challenges along the way. The community near the Bondeni no-take zone initially reported problems with poaching by women from Bweleo and some other initial problems with poaching have been reported as well at the other sites. Most of the poaching problems tend to be by persons from neighboring villages. For example before the festive month of Ramadhan in November 2008 there was a reportedly high level of poaching especially at the Bondeni site as people prepared themselves for the Idd celebration. Hence in future more effort are required to guard and protect these sites during these periods

IMS is conducting research comparing the no-take zones with unprotected areas to assess the benefits of protection from fishing. Preliminary results have shown some areas with increases 
in fish and octopus populations including higher biomass and density of target species (e.g octopus), higher mean size/age of target species, and higher production of propagates (eggs/larvae) of target species per unit area (Ngowo, 2008).

\section{COMMunity-BASEd MONitoring}

The Institute of Marine Sciences (IMS) established a community-based scheme to monitor the effectiveness of the no-take areas. IMS staff provided the community with training on data sampling and analysis. Groups of volunteer monitors, mainly women cockle gatherers, go out on the reef flats during spring tides twice per year when the lowest low tides were experienced on the reef flats. Metal one-meter square transects were laid out on the reef flat and all cockles found in the substrate within the quadrat were counted. In each adjacent and no-take site, 50 to 1001 square meter quadrats were sampled. These quadrats were laid out using a systematic sampling technique. A 100 meter line would be run perpendicular to the no-take zone boundary and quadrats laid at every 10 meter intervals. As each transect was completed, the line would be moved further from the shoreline and another group of quadrats would be sampled. Baselines were established in September 2006.

This monitoring is carried out by the community with technical and logistical support by IMS. Once data is collected, simple bar charts of length frequency distribution are prepared by the community with the assistance of IMS. These results are compared with bar charts drawn during previous monitoring events and trends discussed among the monitoring group and shared with the village committee and other community members.

Community based monitoring data is presented below. Figure 6 shows the mean density of cockles both inside the four no-take zones and in respective adjacent areas over time. While the density was almost the same for each group in Sept 2006, the adjacent areas tended to decline slightly whereas the no-take zones show some increases compared to the 2006 baseline.. These changes in cockle density over time were statistically analyzed. Mean density data was transformed $(\log 10)$ for statistical analysis as raw data was not normally distributed. Results reported below are for the Log 10 transformed data. Changes were not statistically significant for all sampled areas combined, both inside and outside the no take zones (ANOVA: $\mathrm{N}=24$, Multiple R squared $=0.093$, F-ratio $=1.077, \mathrm{p}=0.359$ ). Changes in density over time only in areas outside the no-take zones (ANOVA: $\mathrm{N}=12$, Multiple $\mathrm{R}$ squared $=$ 0.226 , F-ratio $=1.316, p=0.315$ ), and changes in density over time inside the no-take areas were also not significant (ANOVA: $\mathrm{N}=12$, Multiple $\mathrm{R}$ squared $=0.104$, F-ratio $=0.523, \mathrm{p}=$ 0.609 ). 


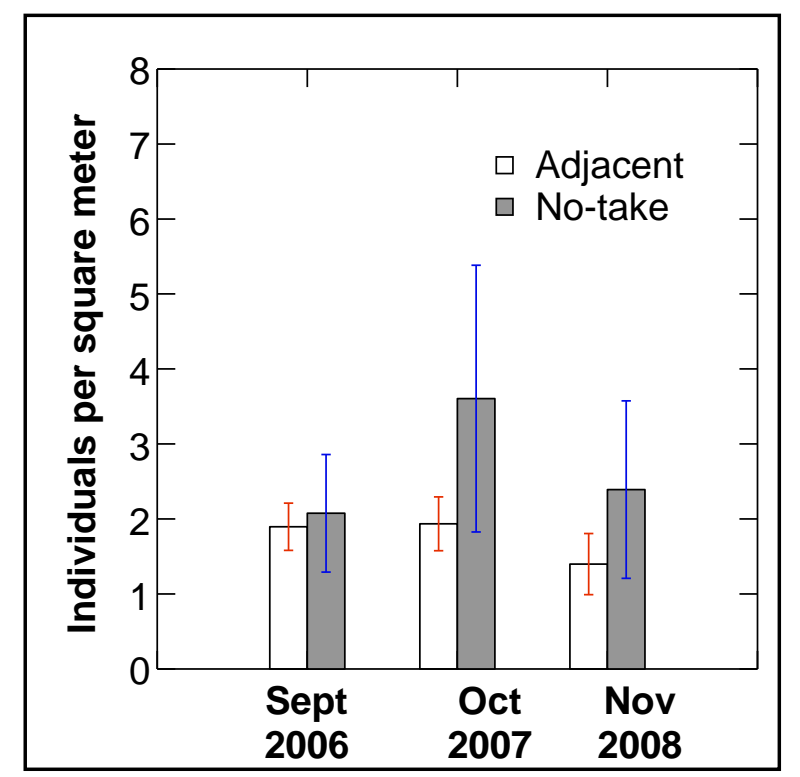

Figure 6. Changes in mean density of cockles inside and outside the no-take zones in Menai Bay, Zanzibar.

Figure 7 below shows data from the Bweleo site between September 2006 and November 2008. At this site, there has been an approximately two-fold build up in the number of individuals inside the no-take zone and a smaller build up in the adjacent areas as well. At least at this one site, these results are what were expected from the establishment of the no-take zones. Figure 8 shows the length frequency of individuals within the Bweleo no-take zone and adjacent site. Anadara antiquata males mature at an average size of $31 \mathrm{~mm}$ and females mature at an average size of $35 \mathrm{~mm}$ (Mzighani 2003). The no-take zone shows a large build up of mature sized adults, creating a larger spawning stock biomass desired inside the no-take zones. While there are an increasing number of larger-sized mature individuals in the adjacent areas, there are also more smaller-sized individuals. This is suggestive that the no-take zone is exporting larvae and seeding the adjacent site with an increasing number of small sized individuals. Bweleo is a bit protected as it is located within the inner bay and also between two points which may help with self replenishment of new cockle recruits from the no-take zone.

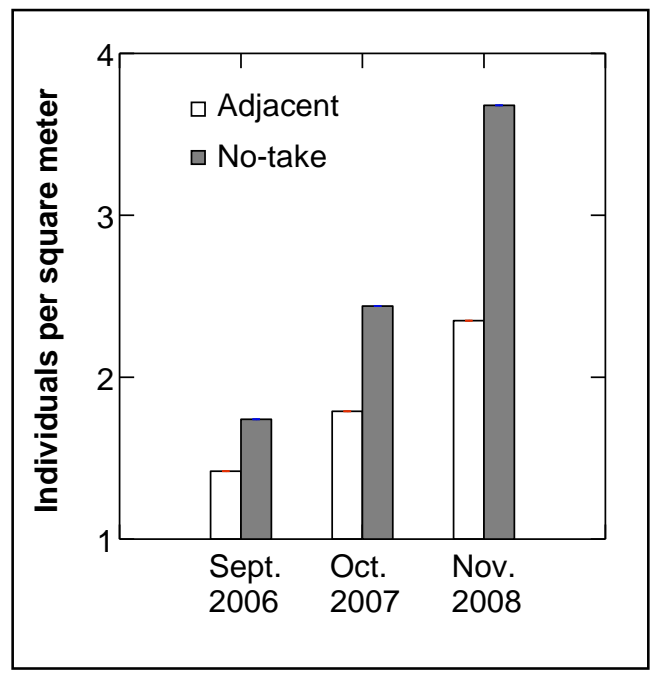

Figure 7. Changes in cockle density in the Bweleo no-take zone and adjacent area. 


\section{LESSONS FROM MENAI BAY}

The monitoring results suggest that a build-up of cockle density inside the no-take zones and increased abundance in adjacent areas is not occurring except in the Bweleo site. These results require a closer examination as to why some of sites other than Bweleo may not be performing as expected. There are several possible explanations. First, one of the no-take sites in Nyamanzi is periodically covered with sand during the southeast monsoon season which leads to high seasonal mortalities of cockles so that a high level of biomass does not build up. Without a high level of biomass build-up, it is unlikely that any significant increase in larval output would be expected. The Project has discussed this issue with the community and recommended that an alternative site be selected that is not subject to shifting sands. A second reason may be that the no-take zone is very small - only 2 ha in area, which may be too small to function effectively and have any real impact.

The two Fumba sites also show no build-up inside the no-take zone or in the adjacent area. No result would be expected in the adjacent area unless there is a build up inside the no-take zone. While physical dynamics of the Nyamanzi site may explain the absence of a build up in that no-take area, the lack of result at the two Fumba sites then remains a mystery. The reported high levels of poaching coinciding with religious festivities in October 2008, just before monitoring took place is the likely explanation for lower abundance of cockles in 2008 (see Figure 6). In this regard, the Fuimba communities may want to consider adopting traditional management practices used in Eastern Indonesia where closed areas are temporarily opened for a few days once a year during traditional celebrations, then closed again (McClanahan et al. 2006). These sites showed increased conservation performance compared to co-managed and centrally managed closures. If residents are given the opportunity to partially harvest the closed areas when larger than expected harvests are needed for special celebrations, then compliance during the rest of the year by the communities may actually be higher, and motivation will also be higher to enforce the closure against outsiders. This is also consistent with the finding that perceived tangible benefits by the community is an key sustainability factor (Pollnac and Pomeroy, 2005).

Another issue that Menai Bay communities and the MBCA need to consider is that combined, the four no-take zones consist of only 16 hectares of no-take zones. This is only a small fraction of the reef flats in Menai Bay so any small build up inside the no-take zones are unlikely to have a significant impact bay-wide. In the future, more and larger no-take zones will be needed throughout the bay to before any eco-system-wide impact can be expected.

Currently, there is no national initiative to protect molluscan bivalves, which may result into collapse of fishery and may even lead to the loss of some species especially those which are preferred for food like $A$. antiquata. As the way to ensure effective protection of bivalve stocks and species biodiversity, a more integrated management approach is likely needed. In addition to the community based no-take areas, this should go should go hand in hand with setting a minimum length for the cockle to be collected at a size large enough to allow most individuals to reproduce before being harvested. Ngowo (2008) recommended a $48 \mathrm{~mm}$ shell length as the minimum size of collection to maximize reproductive output. However, as illustrated in Figure 8 , this is well above the length of most individual found in open areas. The mean size of all cockles in areas monitored outside the no take zones was between $25-30 \mathrm{~mm}$. This is well below the size recommendation of Ngowo (2008) and below the average reproductive size reported by Mzighani (2003). Implementing such a size limit would greatly reduce harvests and might therefore lead to high non-compliance issues. An alternative strategy may be to 
gradually implement a minimum size limit starting a smaller size and increasing that size annually, and distributing sorting gauges to all harvesters and conducting intensive awareness campaigns concerning the rationale for size limits.

\section{Conclusions}

The project premise that the co-management approach to small scale management of gleaned shellfish (Anadara spp.) using small-scale no-take marine reserves has widespread applicability was demonstrated by the two cases presented above. The Western Pacific experience was transferred to Tanzania and Nicaragua, but in both instances however, a significant level of adaptation to local context was necessary to make this approach effective. In addition, the role of enabling environment proved important in both the Nicaragua and Tanzanian cases. Explicit policies that promote this approach at a national scale are not in place or as well developed as in Fiji. However, in both cases, the pilot project has started to make inroads to influence policy even though formal policy changes at the national scale have not yet been instituted. This demonstrates the need for considerable time to foster larger scale change emanating form pilot experience even if scaling up to other geographic areas is taking place without an explicit national policy.

In each of the cases presented here, while a focus was on sustainable fisheries, an integrated approach was applied where sustainable fisheries was an initial entry point. In Tanzania, supplemental livelihoods in shellcraft and pearl farming helped build support and empower the women cockle gathers. In Nicaragua, mangrove and water quality are being built into the process. In both cases, there is a need to scale up within the ecosystem - either to more or larger no-take reserves as well as building in additional management measures such as size limits and communal use rights to fully manage the cockle fisheries sustainably. However, the experience suggests that small scale fisheries can be an entry point for integrated coastal management as well as ecosystem based management, where the process and issues addressed builds incrementally from simple beginnings to larger more complex initiatives over time.

While each of these pilots assisted only a few small communities and may be viewed as an example of community-based management, in each case local and national governments played important roles providing legitimacy and endorsement of community management responsibilities. In reality, these are examples are better characterized as a form of comanagement.

Community monitoring played an important role in each case. In Nicaragua, communities were able to see how their own data demonstrated the link between the closures and increasing abundance of harvestable stocks. In the case of Tanzania, monitoring is helping to expose problems with poor initial site selection and possible poaching, resulting in adjustments to the management plan. This process has also helped communities become advocates for policy reform due their beliefs of perceived benefits from their actions. While community pressure coupled with good documentation of process and results are important to influence decision makers, it may take years before such changes can finally occur.

Universities can play an important role in innovation and catalyzing policy change as decision makers are likely to pay more attention if credibility local scientists are behind these initiatives. However, university researchers need to learn how to blend applied research with practical community extension skills. Learning by doing is an effective capacity building approach for 
local universities and also demonstrates that the Land Grant/Sea Grant extension model is also applicable beyond the U.S.

The type of extension approach is important to success. Field staff with good leadership, facilitation and communication skills are necessary, but in both of these cases, they do not necessarily need to live full time in the community to be effective if the frequency of contact between the extension worker and community is high. While project activities are focusing on implementation success at the pilot site, it is also important to start to plan how extension strategies can start to scale-up beyond a pilot intervention site. This includes providing horizontal scale-up to new geographic sites and vertical-up to influence enabling policies as necessary. However, such scale up can require significant resources that need to be at the ready to take advantage of opportunities as they arise.

It is often difficult to get a quick impact or result, even within a four to five year time frame, especially if the project is attempting to build the performance capacity of local institutions while at the same time trying to show impact on the ground. Even for CBM interventions, time is needed for results to emerge, especially in dealing with new ideas and approaches. Scalingup is critical for larger scale impact in the long term, but it may take many years, often beyond the life of a donor initiative. This is why working with local institutions such as IMS and CIDEA is so important, as they can carry the initiatives and experience well beyond a project's life. Equally important however is building commitment and capacity within the government institutions with ultimate authority for fisheries management. These local institutions university and government - acting in concert, can act as catalysts for the adoption of management innovations at the community level, if they have the capacity and commitment as well as supportive local constituencies of resource users. Outside local institution with long term interest in the communities is another key to sustaining these innovations at the community scale. It should not always be viewed that at some point communities should be left with no outside support. Continuing interventions from external organizations has been demonstrated to be a key success factor for sustainability of community-based initiatives (Pollnac et al. 2001.). In these two cases, similar to the Fiji archetype, universities played key catalytic and technical support roles. This is not to say that competent non-governmental organizations (NGOs) are incapable of playing a similar role. However, local universities sometimes have a unique place in society that may makes it easier for them to bring in new ideas and influence policy makers at a national level, especially in cases where NGOs may be viewed with some suspicion by government.

A small amount of funds on a targeted theme such as CBM can start to foster national changes. In Zanzibar and Nicaragua, interest and acceptance of CBM is growing and highly likely to influence policy in the future beyond the life of the project, even if neither site quite reached that point of impact yet. However, if strong supporting institutions such as CIDEA and IMS are built in the process, then they are likely to carry the benefits and impacts well beyond those seen during the life of the project. All too often, only at the number of hectares of resources protected or people benefiting at the pilot site scale are considered in judging project success. However, it may be that capacity building of these local institutions and of their personnel to implement applied research - extension systems is the greatest value and long term impact of what the project leaves behind. 


\section{References}

Beddington, J.R., D.J. Agnew and C.W. Clark. 2007. Current Problems in the management of marine fisheries. Science 316: 1713-1716.

Bene, C. and A. Tewfik. 2003. Biological evaluation of marine protected area: Evidence of crowding effect on a protected population of queen conch in the Caribbean. Marine Ecology 24(1): 45-58.

Crawford, B.R., A. Siahainenia, C. Rotinsulu, and A. Sukmara. 2004. Compliance and enforcement of community-based coastal resource management regulations in North Sulawesi, Indonesia. Coastal Management 32(1): 39-50.

Diamond, N. 2006. Fisheires Opportunities Assessment. Appendix 4: Capture fisheries and gender. US Agency for Internatinal Development, Coastal Resources Center, University of Rhode Island and Florida International University. 18p.

Eco consultants. 2005. Rapid assessment of the MBCA. MACEMP, Ministry of Agriculture Livestock and Natural Resources. MALE. 107p.

Gutierrez, E. 2005. Estudio de mercado de moluscos otras, mejillones y almejas en Centroamèrica y del mercado interno de conchas negras en Nicaragua.Centro de Investigación de Ecosistemas Acuáticos, Universidad Centroamericana. 33p.

Halpern, B.S. and R.R. Warner. 2002. Marine reserves have rapid and lasting effects. Ecology Letters 5: 361-366.

Halpern, B.S. 2003. The impact of marine reserves: Do reserves work and does reserve size matter? Ecological Applications S13: S117-S137.

Hilborn, R. 2007. Moving to sustainability by learning from successful Fisheries Ambio 36(4): 296-303.

Jackson, J. B. C. et al. 2001. Historical overfishing and the recent collapse of coastal ecosystems. Science 293: 629-638

Kasigwa, P.F. and C.G. Mahika. 1991. The diet of the edible cockle Anadara antiquata L. (Bivalvia, Arcidae) in Dar es Salaam, Tanzania, during the northeast monsoons. Hydrobiologia, 209: 7-12.

Kayombo, N. A. 1986. Growth and reproductive activities in a bivalve Anadara antiquata on the Dar-es-Salaam coast. MSc. Dissertation, University of Dar es Salaam. 99p.

Kayombo, N. A. \& J. R. Mainoya, 1986. Cockle harvesting on the Dar es Salaam coast. In: Status and Utilization of Mangroves. Mainoya, J.R. \& P.R. Siegel (Eds), Faculty of Science Publications, University of Dar es Salaam. p.71-79.

Kite-Powell, H. Jiddawi, N. S and Mmochi, A. 2005. Integrated seaweed and shellfish farming on Zanzibar: A pilot project. Final report to the McNight Foundation, April 2005. $12 \mathrm{p}$.

Makame K. M, Mohammed S M, Ameir H Ali and Soud M.J. 2004. Menai Bay Mangrove Management Plan 2005 - 2010. 25p.

Marroquin-Mora, D.C. and M.A. Rice. 2008. Gonadal cycle of northern quahogs, Mercenaria mercenaria (Linne, 1758), from fished and non-fished subpopulations in Narragansett Bay. J. Shellfish Res. 27(4): 643-652. 
Matthes, H. 1974. Coastal and Estuarine aquaculture. In: Msangi, A.S and Griffin (Eds). International conference on marine resource development in Eastern Africa. University of Dar es Salaam. p.28-37.

McClanahan, T. R., and S. Mangi. 2001. Spillover of exploitable fishes from a marine park and its effect on the adjacent fishery. Ecological Applications 10: 1792-1805.

McClanahan,T.R., M.J. Marnane, J.E. Cinner and W.E. Kiene. 2006. Comparison of marine protected areas and alternative approaches to coral-reef management. Current Biology 16: $1408-1413$.

Murawski, S. A., Brown, R., Lai, H.L., Rago, P. J. and Hendrickson, L. 2000. Large-scale closed areas as a fisheries management tool in temperate marine systems: the Georges bank experience. Bulletin of Marine Science 66: 775-798.

Mwaiseje, B. 1982. The potential for non-conventional fisheries in Tanzania. University Science Journal (Dar. Univ.): 8(1 \& 2): 35-42.

Myers, R.A. and B. Worm. 2003. Rapid worldwide depletion of predatory fish communities. Nature 423: 280-283.

Mzighani, S. 2003. Fecundity and population structure of cockles, Anadara antiquata L. 1758 (Bivalvia: Arcidae) from a sandy/ muddy beach near Dar es Salaam, Tanzania. Western Indian Ocean Journal of Marine Sciences 1: 77-84.

Ngowo R, G 2008 Role of small scale community based marine no-take areas in coanservation of Anadara antiquata in Fumba peninsula. Draft Manuscript. IMS. 95p.

Pauly, D. V. Christensen, J. Dalsgaard, R. Froese, F. Torres Jr. 1998. Fishing down marine food webs. Science 279(5352): 860-863.

Pollnac, R. B., B.R. Crawford and M. Gorospe. 2001. Discovering factors influencing the success of community-based marine protected Areas in the Visayas, Philippines. Ocean \& Coastal Management 44: 683-710.

Pollnac, R.B. and R. Pomeroy. 2005. Factors influencing the sustainability of integrated coastal management projects in the Philippines and Indonesia. Ocean \& Coastal Management 48: 233-251.

Rice, M.A., C. Hickox, \& I. Zehra. 1989. Effects of intensive fishing effort on the population structure of quahogs, Mercenaria mercenaria (Linnaeus, 1758), in Narragansett Bay. $J$. Shellfish Res. 8: 345-354.

Rice, M.A. 2006. Quahog (Mercenaria mercenaria) spawner sanctuaries: does size or location matter? J. Shellfish Res. 15:271-283.

Roberts, C., J. Bonsack, FR Gel, JP Hawkins and R. Goodridge. 2001. Effects of marine reserves on adjacent fisheries. Science 294: 1920-1923.

Russ, G. R., and A. Alcala. 1996. Do marine reserves export adult fish biomass? Evidence from Apo Island, Central Philippines. Marine Ecology 132:1-9.

Shunula J.P. 2005. A comparison of shell size and meat weight between populations of the bivalve Anadara antiquata (Linnaeus 1758) from four sites experiencing different levels of exploitation pressure in Zanzibar. Tanzania Journal of Science.

Tawake, A., J. Parks, P. Radikedike, B. Albersberg, V. Vuki and N. Salafsky. 2001. Harvesting clams and data. Conservation Biology in Practice 2(4): 32-25. 
Williams, M.J., M.C. Nandeesha and P.S. Choo. 2004. Changing traditions: First global look at the gender dimensions of fisheries. In: Symposium on gender and fisheries, $7^{\text {th }}$ Asian Fisheries Forum, 1-2 December 2004, Penang Malaysia. 